\title{
Characterization of the Immunoglobulin Heavy Chain Complementarity Determining Region (CDR)-III Sequences from Human B cell Precursor Acute Lymphoblastic Leukemia Cells
}

\author{
Hitoshi Kiyoi," Tomoki Naoe," Keizo Horibe, ${ }^{\star}$ and Ryuzo Ohno* \\ "Department of Medicine, the Branch Hospital Nagoya University School of Medicine, Higashi-ku, Nagoya 461, Japan; \\ and ${ }^{\ddagger}$ Department of Pediatrics, Nagoya University School of Medicine, Showa-ku, Nagoya 466, Japan
}

\begin{abstract}
Sequence analysis of the immunoglobulin heavy chain complementarity determining region (CDR)-III of B-lineage cells at various stages has provided important insights concerning $B$ cell maturation and selection. Knowledge of human CDR-III sequences has been relatively limited compared with that of the murine system. We analyzed the CDR-III sequences of $B$ cell precursor acute lymphoblastic leukemia (pre-B ALL) cells in 23 newly diagnosed and 10 relapsed patients, in order to elucidate the organization of CDR-III in B cell precursors. We found a very low frequency of somatic mutations in $D$ and $J_{H}$ regions, preferential use of $D_{L R}, D_{X P}, D_{H Q 52}$, and $D_{N}$ elements, and of $3^{\prime}$ side $J_{H}$ segments, and no predominant usage of $D$ coding frames. Unusual joinings such as $V_{H^{-}}-\mathbf{D}-\mathbf{D}-J_{H^{-}}$and $V_{H^{-}}$ $J_{H}$ were observed in three, and one sequences, respectively. We compared the CDR-III sequences derived from 10 patients between diagnosis and relapse. Two of them had three spots of mutated nucleotides at relapse, all of which were found in the $\mathbf{N}$ region near the $D$ segments. Our data showed the possibility of somatic mutation at relapse, in addition to developmentally regulated rearrangement of the immunoglobulin gene at the stage of B cell precursors. (J. Clin. Invest. 1992. 89:739-746.) Key words: immunoglobulin • CDR-III • pre-B ALL • somatic mutation • PCR
\end{abstract}

\section{Introduction}

The immunoglobulin heavy chain $(\operatorname{IgH})^{1}$ variable region is encoded by three separate genes: variable $\left(\mathrm{V}_{\mathrm{H}}\right)$, diversity $(\mathrm{D})$, and joining $\left(\mathrm{J}_{\mathrm{H}}\right)$ segments. During $\mathrm{B}$ lymphocyte differentiation, the IgH gene is assembled in two steps. $D$ and $J_{H}$ segments are joined first, followed by $V_{H}$ to $D-J_{H}$ joining. During these joining steps, antibody diversity is generated by the following mech-

Address correspondence and reprint requests to Tomoki Naoe, Department of Medicine, the Branch Hospital Nagoya University School of Medicine, 1-1-20, Daiko-Minami, Higashi-ku, Nagoya 461, Japan

Received for publication 19 March 1991 and in revised form 13 September 1991 .

1. Abbreviations used in this paper: $\mathrm{CDR}$, complementarity determining region; $D$, diversity segment; dd-NTP-Fs, four dideoxynucleotide terminators; IgH, immunoglobulin heavy chain; $\mathrm{J}_{\mathrm{H}}$, joining segment $\mathrm{P}$, palindromic; PCR, polymerase chain reaction; pre-B ALL, B cell precursor acute lymphoblastic leukemia; SSC, standard saline citrate; $\mathrm{Tdt}$, terminal deoxynucleotidyl transferase; $\mathrm{V}_{\mathrm{H}}$, variable segment.

J. Clin. Invest.

(C) The American Society for Clinical Investigation, Inc. 0021-9738/92/03/0739/08 \$2.00

Volume 89, March 1992, 739-746 anisms: (a) somatic recombination of multiple $V_{H}, D$, and $J_{H}$ segments; $(b)$ variation of joining sites and addition of the $\mathrm{N}$ region nucleotides; and (c) somatic mutation (1-3).

The assembled variable region of the Ig gene contains three hypervariable regions surrounded by framework regions that are relatively well conserved. These regions are called complementarity determining regions (CDR)-I, II, and III, and are thought to contact the antigenic epitope directly (1-4). CDR-I and II are encoded by a $V_{H}$ segment, and CDR-III is encoded by $D$ elements, $V_{H}-D$ and $D-J_{H}$ junctional segments. As a result of these mechanisms, enormous diversity of CDR-III is created from a limited number of germline D segments (1-3).

In murine system, recent studies have demonstrated several characteristics of the IgH gene at each stage of B cell differentiation. First, the preferential use of the most $5^{\prime} \mathrm{D}$ segments, and the most $\mathbf{J}_{\mathbf{H}}$-proximal D segments, is developed during initial D to $J_{H}$ joining in immature $B$ cells (5). Second, the CDR-III sequences from fetal and neonatal $B$-lineage cells preferentially use the $\mathrm{J}_{\mathrm{H}}$-proximal $\mathrm{V}_{\mathrm{H}}$ genes (6-9). In contrast, adult B-lineage cells show random $V_{H}$ utilization (9-13). Third, $N$ region nucleotides are thought to be added by the enzyme terminal deoxynucleotidyl transferase (TdT) (14-17), and very few $\mathrm{N}$ region nucleotides are observed in most fetal and neonatal $\mathrm{V}_{\mathrm{H}^{-}}$ D- $\mathrm{J}_{\mathrm{H}}$ junctional sequences. The addition of $\mathrm{N}$ regions thus appears to be a developmentally regulated process in B cells (18-20). Fourth, one particular reading frame of the D elements is preferentially used in productively rearranged $V_{H^{-}}-D-$ $\mathrm{J}_{\mathrm{H}}$ genes, and other reading frames are used at the stage of D- $\mathrm{J}_{\mathrm{H}}$ joining, although the joining border varies in each clone $(21$, 22 ). It is suggested that the selection of reading frames is developmentally regulated at the stage of B cell ontogeny.

In the human system, $\mathrm{D}_{\mathrm{HQ} 52}-\mathrm{J} 1$ joining was frequently observed in Epstein-Barr virus-transformed fetal B cell lines (23). Another study showed the biased use of $\mathrm{J}_{\mathrm{H}}$ segments $(\mathrm{J} 3>\mathrm{J} 4$ $>\mathrm{J} 5>\mathrm{J} 1, \mathrm{~J} 2$ ) and the $\mathrm{D}_{\mathrm{HQ} 52}$ element in fetal liver (24). Recently Yamada et al. reported that $3^{\prime}$ side $\mathrm{J}_{\mathrm{H}}$ segments ( $\mathrm{J} 4, \mathrm{~J} 5$, and J6) were preferentially used, and all coding frames of germline $\mathrm{D}$ genes were used to generate CDR-IIIs in adult human peripheral B cells (25). Until now, molecular studies of human B-lineage malignancies at various stages have provided many insights into B cell ontogeny. For example, follicular B cell lymphoma has extensive somatic mutations in the $V_{H}$ regions (26-28), although B cell precursor leukemia has few mutations (29).

In this study, in order to elucidate the characteristics of CDR-III at the stage of B cell precursors, we have analyzed the CDR-III sequences from human B cell precursor acute lymphoblastic leukemia (pre-B ALL) cells using the polymerase chain reaction (PCR) amplification and a fluorescent chain-terminating dideoxy-nucleotide sequencing system. We demonstrate here the structure of the $\mathrm{N}$ region, the low frequency of somatic 
mutations in the $\mathrm{D}$ and $\mathrm{J}_{\mathrm{H}}$ regions, and the segments in the $\mathrm{D}$ and $\mathrm{J}_{\mathbf{H}}$ genes which are preferentially used. In addition, we compared the CDR-III sequences between initial diagnosis and relapse, and found the possibility of somatic mutation in pre-B ALL cells at relapse.

\section{Methods}

Leukemia cells. Bone marrow samples were taken from 23 patients (13 children and 10 adults) with pre-B ALL at the time of initial diagnosis or relapse, after informed consent was obtained. All bone marrow samples contained over $90 \%$ leukemia cells. The diagnosis of ALL in each patient was confirmed by standard morphological and immunophenotyping studies. All leukemia cells had an L1 or L2 French-AmericanBritish (FAB) subtype, expressed HLA-DR, CD10, and CD19 antigens, and lacked immunophenotypic evidence of both $\mathrm{T}$ (CD1, CD2, CD3, CD4, CD5, CD7, CD8) and mature B-cell lineage (CD20 and surface Ig). The expression of cytoplasmic $\mu$ chain and TdT was examined by an immunofluorescence test. Karyotypic analysis revealed that five patients (patients S.B., S.I., F.K., S.M., and C.S.) had the Philadelphia chromosome $\left(\mathrm{Ph}^{1}\right)$. In the 10 relapsed patients, the morphological, immunophenotypical, and karyotypical features of their leukemia cells were identical with those at initial diagnosis. These data are summarized in Table I.

Southern blot analysis. High molecular weight DNA was extracted from leukemia cells according to a previously published method (30). Rearrangements of the IgH gene were analyzed by Southern blot analysis (31), using a probe made of the subcloned 4.3-kb fragment (PstIHindIII) from the genomic clone containing $J_{H}$ region. High molecular weight DNA from pre-B ALL was digested with HindIII, EcoRI, or a combination of HindIII and BamHI restriction endonucleases (Boehringer Mannheim Yamanouchi, Tokyo, Japan), electrophoresed in an $0.8 \%$ agarose gel, and blotted onto nitrocellulose membranes. Hybridization was carried out with ${ }^{32} \mathrm{P}$-labeled nick-translated probes under previously published conditions (31). Membranes were washed twice with $2 \times$ standard saline citrate (SSC), containing $0.1 \%$ SDS, and twice with $0.1 \times$ SSC, containing $0.1 \%$ SDS and exposed to $x$-ray films.

Oligonucleotide primers. Oligonucleotide primers for PCR amplification of CDR-III were synthesized on a DNA synthesizer (model 381A; Applied Biosystems, Inc., Foster City, CA). The consensus sequences of the $V_{H}$ and $J_{H}$ segments were determined according to the published sequence data (32-34). Recently, several PCR primers for the amplification of the human IgH CDR-III have been reported (35-37). We also synthesized similar primers: Vcomm: 5'-GAGTC-GAC(A/T)C(A/G)GC(G/C)(G/A)TGTA(T/C)T(T/A)CTG-3', and Jcomm: 5'-CCAAG-CTTACCTGAGGAGACGGTGA-3' that was designed to correspond more specifically to the published IgH sequences than those previously reported. These primers contain SalI and HindIII cloning sites, respectively, to allow ligation of the amplified sequences into recombinant vectors (38).

PCR amplification of the CDR-III sequences. PCR was essentially performed as described by Saiki et al. (39). A $50-\mu l$ reaction mixture contained $500 \mathrm{ng}$ of genomic DNA, $50 \mathrm{mM} \mathrm{KCl}, 10 \mathrm{mM}$ Tris- $\mathrm{HCl}$ (pH 8.4), 1.0 to $1.5 \mathrm{mM} \mathrm{MgCl}, 100 \mu \mathrm{g} / \mathrm{ml}$ gelatin, $0.25 \mu \mathrm{M}$ of Vcomm and Jcomm primers, $200 \mu \mathrm{M}$ of each deoxynucleotide triphosphate (dATP, dCTP, dGTP, and dTTP; Boehringer Mannheim Yamanouchi). The reaction mixture was first incubated at $95^{\circ} \mathrm{C}$ for $10 \mathrm{~min}$ to denature double-stranded DNA, followed by $1 \mathrm{~min}$ at $55-58^{\circ} \mathrm{C}$ to anneal primer and template. Primer extension was started by the addition of $2.5 \mathrm{U}$ Taq polymerase (AmpliTaq; Perkin-Elmer Cetus Corp., Norwalk, CT), and allowed to proceed for $1 \mathrm{~min}$ at $72^{\circ} \mathrm{C}$. Subsequent denaturing, annealing, and extension steps were performed at $92^{\circ} \mathrm{C}$ for $1 \mathrm{~min}$, at 55 to $58^{\circ} \mathrm{C}$ for $1 \mathrm{~min}$ and at $72^{\circ} \mathrm{C}$ for $1 \mathrm{~min}$, respectively, for 40 cycles on a program temperature control system (model PC-700; Astec, Fukuoka, Japan).

DNA sequencing of amplified fragments. The amplified fragments were separated through $4 \%$ NuSieve GTG agarose gels (FMC BioProd- ucts, Rockland, ME) and $12 \%$ polyacrylamide gels in TBE buffer (0.09 $M$ Tris-borate, 0.002 M EDTA: $\mathrm{pH}$ 8.0). Amplified fragments were isolated from the polyacrylamide gels by the crush and soak technique, then digested with SalI and HindIII restriction endonucleases (Boehringer Mannheim Yamanouchi), and ligated to the M13mp18 phage vector (Takara, Kyoto, Japan). The ligated materials were transfected into Escherichia coli strain JM109. More than five recombinant plaques per one clone were picked up and cultured in $2 \times$ TY medium (16 g/liter Bacto-tryptone; Difco Laboratories, Inc., Detroit, $10 \mathrm{~g} /$ liter Bacto-yeast extract; Difco Laboratories, $5 \mathrm{~g} /$ liter $\mathrm{NaCl}$ ). Singlestranded phage DNA was prepared from these cultures. DNA was sequenced using fluorescent chain-terminating dideoxynucleotides on a Genesis 2000 (DuPont Co., Wilmington, DE) (40). This sequencing system uses a special set of four dideoxynucleotide terminators (ddNTP-Fs), each having a unique member of the succinyl fluorescein family attached. Single-stranded phage DNA, M13 M1-primer (Takara), and reaction buffer were heated at $90^{\circ} \mathrm{C}$ for $2 \mathrm{~min}$ and then transferred to a $37^{\circ} \mathrm{C}$ water bath for $10 \mathrm{~min}$ to allow the primer to anneal. At this time, a single solution containing a mixture of each deoxynucleotide triphosphate (dCTP, dTTP, 7-deaza dATP, and 7deaza dGTP), dd-NTP-Fs, DTT, and T-7 DNA polymerase (Takara) was prepared. An aliquot of this solution was added to the annealed mixture, and after a 5-min incubation, the unincorporated nucleotide, proteins, and reaction buffer were removed by ammonium acetate/ethanol precipitation. The DNA was washed with $70 \%$ ethanol and dried up, followed by resuspension in the loading solution. The mixture was then applied to the auto sequencer (Genesis 2000; DuPont Co.). The sequence data of each clone was determined if all the sequences from each recombinant plaque were identical.

\section{Results}

Southern blot analysis. All leukemia cells analyzed here demonstrated rearranged bands of the $\mathbf{J}_{\mathbf{H}}$ region in either HindIII, EcoRI, or the combination of HindIII and BamHI digests. In the 10 relapsed patients, the rearranged patterns were identical with those at initial diagnosis (summarized on Table I).

Analysis of the CDR-III sequences from pre-B ALL. All genomic DNAs from the pre-B ALL cells were well amplified using the Vcomm and Jcomm primers. However, DNA from normal peripheral blood lymphocytes did not result in a signifcant band, and gave a faint smear after an additional 40-cycle PCR amplification (data not shown). In patient S.I., two amplified bands were observed that presumably corresponded to two rearranged IgH genes. We analyzed both bands and determined their CDR-III sequences.

The CDR-III sequences from the pre-B ALL cells are shown in Fig. 1. In the amplified sequences from all patients except T.E., we could determine $D$ elements followed by $\mathbf{J}_{\mathbf{H}}$ sequences. In patient T.E., a $V_{H}$ gene joined directly to a $J_{H}$ gene without a $D$ region. Similar joining clones have been reported in peripheral $B$ cells (25). We do not know if this joining results from deletions of the $D$ region during $V_{H}$ to $D-J_{H}$ joining, or whether it reflects extensive exonuclease modification of the $D$ region in the $V_{H}-D-J_{H}$ gene.

$D$ segment. All D-coding elements were tentatively assigned to germline $D$ segments $(32,41,42)$. Somatic mutations of $D$ elements were rare $(4 / 412 ; 0.97 \%)$, although three patients (K.N., N.K., and C.S.) showed mutated D elements: CA to TG in $D_{\mathrm{N} 1}$; $A$ to $G$ in $D_{\mathrm{HQ} 52}$; and $G$ to $C$ in $D_{\mathrm{HQ} 52}$, respectively. The DNAs obtained from these three patients at the time of both initial diagnosis and relapse were independently analyzed. The sequences of the mutated $\mathrm{D}$ elements were completely identical in each patient. The D element of patient K.N. may be 
Table I. Clinical and Laboratory Data of Patients with Pre-B ALL

\begin{tabular}{|c|c|c|c|c|c|c|}
\hline Patient & Age & Sex & $\mathrm{D} / \mathrm{R}^{*}$ & $\mathrm{~J}_{\mathrm{H}}(\text { HindIII })^{\ddagger}$ & $\mathrm{TdT}$ & $\mathrm{C} \mu$ \\
\hline & $y r$ & & & & $\%$ & \\
\hline \multirow[t]{2}{*}{ MS } & 1 & F & D & $G / R / R$ & NT & NT \\
\hline & & & $\mathbf{R}$ & $\mathrm{G} / \mathrm{R} / \mathrm{R}$ & NT & NT \\
\hline \multirow[t]{2}{*}{ YM } & 2 & $\mathbf{M}$ & D & $\mathrm{G} / \mathrm{R}$ & NT & NT \\
\hline & & & $\mathbf{R}$ & $G / R$ & NT & NT \\
\hline TH & 2 & $\mathbf{M}$ & $\mathrm{D}$ & NT & 80 & - \\
\hline MK & 3 & $F$ & D & G/R/R & NT & - \\
\hline $\mathbf{R F}$ & 6 & $\mathbf{M}$ & $\mathrm{D}$ & $\mathrm{G} / \mathrm{R}$ & NT & - \\
\hline SB & 7 & $\mathbf{M}$ & D & $\mathrm{G} / \mathrm{R}$ & 60 & - \\
\hline \multirow[t]{2}{*}{$\mathrm{SE}$} & 9 & $F$ & D & $\mathrm{G} / \mathrm{R} / \mathrm{R}$ & NT & NT \\
\hline & & & $\mathbf{R}$ & G/R/R & NT & NT \\
\hline \multirow[t]{2}{*}{$\mathrm{KN}$} & 10 & $\mathbf{M}$ & D & $\mathrm{G} / \mathrm{R}$ & 70 & - \\
\hline & & & $\mathbf{R}$ & $\mathrm{G} / \mathrm{R}$ & NT & - \\
\hline $\mathrm{HI}$ & 10 & $\mathbf{M}$ & D & $\mathrm{G} / \mathrm{R} / \mathrm{R}$ & 70 & - \\
\hline HT & 10 & $\mathbf{M}$ & D & $\mathrm{G} / \mathrm{R}$ & NT & + \\
\hline \multirow[t]{2}{*}{ NK } & 10 & $\mathbf{M}$ & D & $\mathrm{G} / \mathrm{R}$ & NT & NT \\
\hline & & & $\mathbf{R}$ & $\mathrm{G} / \mathrm{R}$ & NT & NT \\
\hline \multirow[t]{2}{*}{ TY } & 11 & $\mathbf{M}$ & D & $G / R$ & 30 & - \\
\hline & & & $\mathbf{R}$ & $G / R$ & 30 & - \\
\hline SH & 12 & $\mathrm{~F}$ & $\mathrm{D}$ & $\mathrm{G} / \mathrm{R}$ & NT & - \\
\hline \multirow[t]{2}{*}{$\mathrm{KM}$} & 18 & $\mathrm{~F}$ & D & $G / R / R$ & NT & + \\
\hline & & & $\mathbf{R}$ & $G / R / R$ & 70 & + \\
\hline \multirow[t]{2}{*}{ EY } & 18 & $\mathrm{~F}$ & D & $G / R / R$ & NT & - \\
\hline & & & $\mathbf{R}$ & $\mathrm{G} / \mathrm{R} / \mathrm{R}$ & NT & - \\
\hline YI & 20 & $\mathbf{M}$ & D & $\mathrm{G} / \mathrm{R}$ & 70 & - \\
\hline $\mathrm{TE}$ & 24 & $\mathbf{M}$ & D & $\mathrm{G} / \mathrm{R}$ & 80 & - \\
\hline \multirow[t]{2}{*}{ MH } & 24 & $F$ & $\mathrm{D}$ & $G / R / R$ & 60 & + \\
\hline & & & $\mathrm{R}$ & $G / R / R$ & 90 & + \\
\hline HM & 25 & $\mathbf{M}$ & D & $G / R / R$ & 70 & - \\
\hline SI & 47 & $\mathbf{F}$ & D & $G / R / R$ & 80 & - \\
\hline SM & 55 & $\mathbf{M}$ & D & G/R & 60 & - \\
\hline FK & 57 & $\mathbf{M}$ & D & $\mathrm{G} / \mathrm{R} / \mathrm{R} / \mathrm{R}$ & 90 & + \\
\hline \multirow[t]{2}{*}{ CS } & 57 & $\mathrm{~F}$ & D & $\mathrm{G} / \mathrm{R} / \mathrm{R}$ & NT & - \\
\hline & & & $\mathbf{R}$ & G/R/R & 90 & - \\
\hline
\end{tabular}

* $\mathrm{D}$ and $\mathrm{R}$ indicate diagnosis and relapse, respectively.

₹ Rearranged pattern of Southern blot hybridization are indicated. G, germline band; R, rearranged band. C $\mu$, cytoplasmic $\mu$ chain. NT, not tested.

encoded by another member of the $D_{N}$ gene family, since the same sequences were reported as being frequently found in peripheral B cells (25). Similarly, the $D_{K 4}$ element in patient S.B. that was matched in a narrow region might be encoded by another member of the $D_{K}$ gene family.

The frequencies of $\mathrm{D}$ segment use in human pre-B ALL cells are shown in Fig. 2. To clarify our data, previously described CDR-III sequences from pre-B ALL cells are also shown in Fig. $2(29,36,37,43)$. The $D_{L R}$ family was most frequently used (our data: $41 \%$, published data: $48 \%$ ). The frequency of the $\mathrm{D}_{\mathrm{XP}}$ family (our data: $29 \%$, published data: $29 \%$ ) was a little lower than that of the $D_{L R}$ family. The $D$ segment usage frequency gradient, i.e., $D_{L R}>D_{X P}>D_{H Q 52}, D_{N}>D_{K}$, $D_{A}>D_{M}$, is similar to the published data $(29,36,37,43)$.

It is noteworthy that three clones contained D-D joining sequences. In patient T.Y., both sequences at the time of initial diagnosis and relapse had the same D-D joins consisting of
$D_{L R 4}, D_{H Q 52}$, and a five-nucleotide $N$ region between these $D$ elements. In patient S.M., D-D join consisted of $D_{L_{R 4}}, D_{X P 4}$, and a seven-nucleotide $N$ region between them. Also in patient H.T., D-D join consisted of $D_{\text {LR4 }}$, and $D_{X P 4}$, with a 12-nucleotide $\mathrm{N}$ region between them (Fig. 1).

Coding frame of $D$ segment. Although all CDR-III sequences shown in Fig. 1 are not necessarily translated, nucleotide sequences corresponding to the $\mathrm{D}$ element are typed in triplets to identify the temporary coding frame. The frame sequence in $V_{H}$ segments were decided to start with $T A(T / C)$ $\mathrm{T}(\mathrm{T} / \mathrm{A}) \mathrm{C}$ TGT. In Table II the coding frames of the D segment are shown. All three coding frames were equally used. Of interest was the use of the first coding frame in the $D_{L R}$ family, which contained the stop codon, and was not used by the peripheral B cells.

$J_{H}$ segment. The $\mathrm{J}_{\mathrm{H}}$ segments of the sequenced clones were assigned to $\mathrm{J} 1-\mathrm{J} 6$ according to published data (32).

It could not be determined whether the $J_{H}$ segment from patient F.K. was assigned to $\mathrm{J} 4$ or $\mathrm{J} 5$, because several nucleotides were deleted at the $5^{\prime}$ coding region of the $J_{H}$ segment. Somatic mutations of eight nucleotides (two nucleotides deleted, four nucleotides substituted, and two nucleotides inserted) were observed in 848 nucleotides encoded by the $\mathbf{J}_{\mathbf{H}}$ segments. This rate $(8 / 848 ; 0.94 \%)$ is almost the same as that $(4 / 412 ; 0.97 \%)$ in the nucleotides encoded by D segments. Furthermore, our sequences of $\mathrm{J} 4, \mathrm{~J} 5$, and $\mathrm{J} 6$ had a discrepancy of one, two, and one nucleotides, respectively, compared with the published germ line sequences (32). However, since these have been reported as germ line polymorphisms (24), we did not include these discrepancies among the numbers described above.

The frequency of $\mathbf{J}_{\mathbf{H}}$ segment use was also examined (Fig. 3 ). There was marked correlation between the $3^{\prime}$ location and $\mathbf{J}_{\mathbf{H}}$ usage. This biased use was similar to previous reports in pre-B ALL $(29,36,37,43)$, and appeared equally in the CDRIII of both children and adults.

$N$ region. We determined the $3^{\prime}$ end of $\mathrm{V}_{\mathrm{H}}$ segment in each clone according to the published $\mathrm{V}_{\mathrm{H}}$ sequences (34). Nucleotides which could not be assigned to any $V_{H}, D$, nor $J_{H}$ segments were determined as $\mathrm{N}$ region. The $\mathrm{N}$ region nucleotides of 1 to 20 bases were observed at the $V_{H}-D$ junction in all clones. In three patients (T.Y., H.T., and S.M.), the $\mathrm{N}$ regions were surrounded by $D$ elements as described above. At the D- $\mathrm{J}_{\mathrm{H}}$ junction, two clones (Y.M. and K.N.) lacked a $\mathrm{N}$ region, and other clones had 1 to 22 nucleotides. GC nucleotides were predominant $(249 / 432 ; 58 \%)$ in the $\mathrm{N}$ region as previously described $(14,44)$ (Fig. 1).

Although TdT is probably a responsible enzyme that mediates the addition of the $\mathrm{N}$ nucleotides (14-17), it was difficult to find a correlation between the expression of TdT in leukemia cells, and the length of the $\mathrm{N}$ nucleotides.

It has been proposed that palindromic (P) regions contribute to junctional diversity (45). The $P$ region consists of dinucleotides palindromic to the coding nucleotides adjacent to the signal heptamer. We found $P$ nucleotides in 14 out of 24 clones, as shown in Fig. 1. However, the contribution of $\mathbf{P}$ nucleotides to the $\mathrm{N}$ region formation of these clones may be difficult to assess, because there was no significant difference between the actual frequency of the inserted $P$ nucleotides (24/ 96; $21 \%$ : number of the $P$ region/number of $V_{H}-N, N-D, D-$ $\mathrm{N}$, and $\mathrm{N}-\mathrm{J}_{\mathrm{H}}$ junctions that could potentially be inserted with $P$ nucleotides.) and that of random nucleotide insertion (25\%). 


\begin{tabular}{|c|c|c|c|c|c|c|}
\hline Case & & $3^{\prime}$ end of & $N, D, N$ region & 5 ' end of $J$ & D & J \\
\hline EY & $\begin{array}{l}D \\
R\end{array}$ & TGOGAGAG & 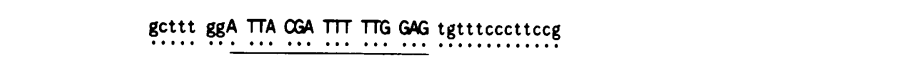 & TGACTACTGGGGOCAĞGGACOCTGG & $X P_{4}$ & 4 \\
\hline SI & D & TGOCAGAGA & 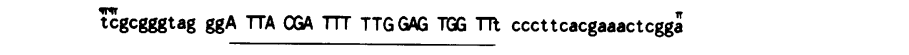 & TACTACTACTACSGTATGGACGTCTGGGGOCAAGGGAOCAOGG & $X P_{4}$ & 6 \\
\hline KM & $\begin{array}{l}D \\
R\end{array}$ & TECAA & 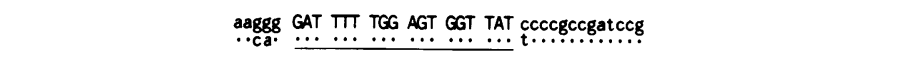 & TGACTACTGGGGOCAGGGA"ACTTGG & $X P_{4}$ & 4 \\
\hline MS & $\begin{array}{l}D \\
R\end{array}$ & TEGAAGAG & ćccggggâ & CTACTACTACTACGGTATGGAOGTTTGGGGÖCAAGGGAOCAOGG & XP1 & 6 \\
\hline YI & D & TGOGAGAG & gC TAT TAC TAT GGT TOG GG" "ccaaagg & 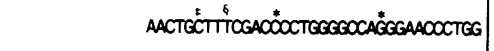 & XP'1 & 5 \\
\hline SI & D & TGOGAGA & ctccatccgtctacg g TG ACT ACt gt & TACTACTACTACTACGGTATCGACGTCTGGGGOCOAGGGGACCAOGG & $A 4 / 1$ & 5 \\
\hline SB & $D$ & $T O O G$ & tccgag $\mathrm{gg}$ T GGT TAC cctctaggac & AACTGGTTOGACOOCTGGGEGAGGGAACOCTGG & K4 & 5 \\
\hline FK & 0 & TEOCAAA & iggtgg GTA TAG CAG CTg gctggtac & GGGGOCAGGGAAOCCTGG & N4 & 45 \\
\hline KN & $\begin{array}{l}\mathrm{D} \\
\mathrm{R}\end{array}$ & T⿱宀一GSAAA & tgg tGG GTA TAG CAG IEG CTG GTA C & 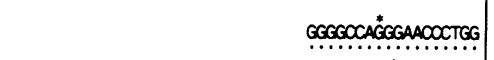 & $\mathrm{N}_{1}$ & 4 \\
\hline MH & $\begin{array}{l}\mathrm{D} \\
\mathrm{R}\end{array}$ & T & tccagtccctccggacgt ggA TAG CAG CAG CTG GTg gggcagctggtaatgggtcgg & ACTGGTTCGACOOCTTGGGGOCAGGGAAOCCTGG & $\mathrm{N}_{1}$ & 5 \\
\hline SE & $\begin{array}{l}D \\
R\end{array}$ & TGCGAGA & ggg gGT AGT AOC AGC TGC ccaatgagcgcccgctgg & TACTACTACGGTATGGACGTCTGGGGÖCAAGGGAOCAOGG & LR4 & 6 \\
\hline HI & $\mathrm{D}$ & TGOGAGATA & 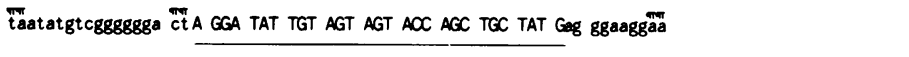 & TACTACTACTACTACGGTATGGACGTCTGGGGÖCAAGGGAOCAOGG & LR4 & 6 \\
\hline MK & D & TGOGAGAG & ttgtttcccgttac ṫaG GAT ATT GTA GTA GTA OCA GCT GCT ATG gağt & ACTACTTTEACTACTGGGGOCAGGGGACOCTGG & LR4 & 4 \\
\hline SH & 0 & TGOGAGAG & "ctga ATT GTA GTA GTA OCA GCT GCT ATG CGc ctgatä & TACTACTACTACTACGGTATGGACGTCTGGGGOCCAAGGGAOCAOGG & LR4 & 6 \\
\hline $\mathrm{HM}$ & D & TGCGAGAGA & C TAT TGT ACT AA g & ACTACTACTACGGTATGGAOGTCTGGGGCOCAAGGGAOCACGG & LRI & 6 \\
\hline RF & D & TGOGAGAGA & gcccgggaaggag gaG GTG GTA Ggc & 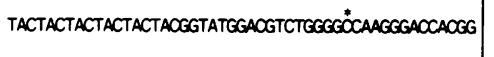 & LR2 & 6 \\
\hline YM & $\begin{array}{l}\mathrm{D} \\
\mathrm{R}\end{array}$ & T⿱\zh21一OGAG & gatg $A T T$ GTG GTG GTG ATT GCT A & TACTACTACTACGGTATGGACGTCTGGGG"COAAGGGAOCAOGG & LR3 & 6 \\
\hline TH & D & TGOGAGAG & ctcagggB TEG GGA gacttt & TACTGGTACTTOGATCTCTGGGGOOGTGGCAOCCTEG & HQ52 & 2 \\
\hline NK & $\begin{array}{l}\mathrm{D} \\
\mathrm{R}\end{array}$ & TGOGAGAGA & agaaggatt taaagtt $g^{\top \mathrm{T}} \stackrel{\mathrm{t}}{\mathrm{GCT} T} \mathrm{GGG}$ att tatgtagt & TACTIGACTACTGGGGOCAGGGACOCTGG & HQ52 & 4 \\
\hline $\operatorname{cs}$ & $\begin{array}{l}\mathrm{D} \\
\mathrm{R}\end{array}$ & Ṭ & 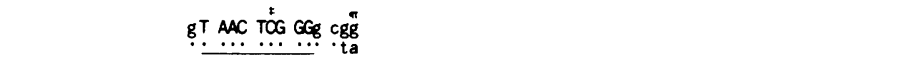 & CTGGGGOCAGGGAACOCTGG & HQ52 & 4 \\
\hline HT & D & TSCAA & aatatcgaaatgag gAC CAG CTG CCa aatgatag ĩ & ACTGGTTOGACOOOCTGGGGOCAGGGAACOCTGG L & $\begin{array}{l}\text { LR4 \& } \\
\times P 4\end{array}$ & 5 \\
\hline TY & $\begin{array}{l}\mathrm{D} \\
\mathrm{R}\end{array}$ & T⿱宀八 & aagat aGA TAT TGT AGT AGT AOC AGC TGC TAT ata taA taA ACT GGG GAa ctaacctttct & TIGACTACTGGGGOCAGGGAGOOOCTGG & $\begin{array}{l}\text { LR4 \& } \\
\text { HQ52 }\end{array}$ & 4 \\
\hline SM & $\mathrm{D}$ & & 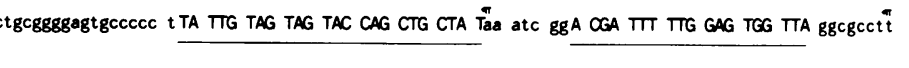 & AGTGGTTOGACOOCTTGGGAOCAGGGAACOCTGG L & $\begin{array}{l}\text { LR4 \& } \\
\times P 4\end{array}$ & 5 \\
\hline TE & $\mathrm{D}$ & $T$ & ācta & ACTACTACTACTAOGGTATGGAOGTCTGGGGÖCAAGGGAOCAOGG & & 6 \\
\hline
\end{tabular}

Figure 1. CDR-III sequences from pre-B ALL cells. D and $\mathrm{R}$ indicate diagnosis and relapse, respectively. $\mathrm{N}$ region nucleotides are indicated by lower-case letters. D elements which could be tentatively assigned to previously described $\mathrm{D}$ genes are underlined. Dots indicate identical nucleotides. * nucleotide discrepancy with previously described germline $\mathrm{J}_{\mathbf{H}}$ segment. These nucleotide discrepancies were developed at the same position in each $\mathbf{J}_{\mathbf{H}}$ segment, and were thought to be germline polymorphisms. ‡ nucleotide mutation. § nucleotide insertion. " nucleotide deletion. I $P$ region nucleotide. 


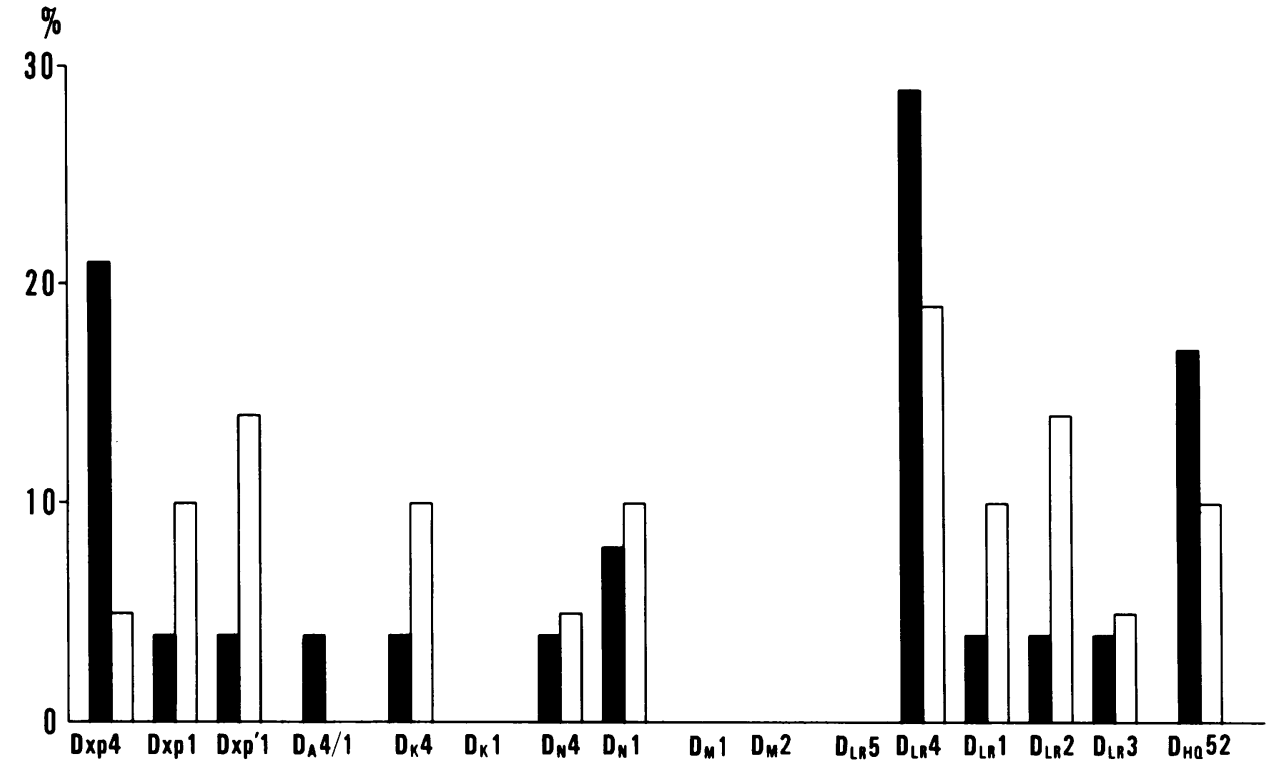

Figure 2. D element usage among human pre-B ALL cells. Distribution of D element among 24 clones sequenced here (black bars), and among 21 clones previously reported (open bars) $(29,36,37,43)$. The clones which could be examined both at initial diagnosis and relapse were counted as one clone.
Comparison of CDR-III sequences between initial diagnosis and relapse. We compared the CDR-III sequences derived from 10 patients between initial diagnosis and relapse. Sequencing data were determined by examining several recombinant clones from each sample to exclude the possibilities of clonal heterogeneity and sequencing error. Although eight of them had completely matched sequences, the other two (K.M. and C.S.) differed by two or three nucleotides. To elucidate that these sequence differences were not due to Taq polymerase replication errors during early stages of the PCR amplification, we amplified genomic DNA from the initial and relapse specimens three times independently, and sequenced five recombinant clones derived from each amplified sample. Since each sequenced data ( 15 clones per one specimen) was completely identical, we could rule out the possibility of Taq polymerase replication errors. The mutated clones at relapse were thought to be the same as the original clones, because Southern blot analysis using $J_{H}$ probe showed similar patterns (Fig. 4). Additionally, in patient K.M., a nucleotide insertion in the $J_{H}$ segment was observed at diagnosis, and also at relapse. In patient C.S., the D element mutation was observed in both clones. These nucleotide differences at relapse were therefore not due to clonal change but to somatic mutation. All these mutations occurred at the $\mathrm{N}$ region. In patient K.M., two nucleotides, GG in the $\mathrm{V}_{\mathrm{H}}-\mathrm{D}_{\mathrm{XP} 4}$ junction, and one nucleotide $\mathrm{C}$ adjacent to the $3^{\prime}$ end of the $D_{\mathrm{XP}_{4}}$ element, had changed to $C A$ and $T$ at relapse, respectively. In patient C.S., two nucleotides GG downstream from the $D_{\mathrm{HQS2}}$ element had changed to TA at relapse (Fig. 1).

\section{Discussion}

Knowledge of the DNA sequences of the human IgH variable region has so far been limited, in contrast to that of the murine system. Recently a rapid cloning and sequencing method for IgH CDR-III using PCR has been developed $(25,35-38,43)$. Using this technique, we analyzed the CDR-III sequences from pre-B ALL cells.

Somatic mutation of the CDR-III sequences from pre-B $A L L$ cells. As mentioned in Results, we found several characteristics of the CDR-III sequences from pre-B ALL cells. So- matic mutation of $D$ and $J_{H}$ segments was very rare (4/412 in D segments, 8/848 in $\mathrm{J}_{\mathrm{H}}$ segments). Furthermore, all of our sequences of $\mathrm{J} 4, \mathrm{~J} 5$, and $\mathrm{J} 6$ had a discrepancy of one, two, and one nucleotides, respectively, compared with published germ line sequences (32). However, since these have been previously pointed out as germline polymorphisms (24), and the majority of sequenced human $\mathbf{J}_{\mathbf{H}}$ segments had the same nucleotide sequences as ours $(24,25,29,36,37,43)$, we did not include these discrepancies among the numbers described above.

Somatic mutation appears to occur at specific stages of B cell development. Bird et al. reported that the rearranged $V_{H}$ genes from pre-B ALL showed no evidence of mutation (29). In

Table II. Usage of D coding Frame

\begin{tabular}{lccc}
\hline & 1st & 2nd & 3rd \\
\hline DXP4 & $4(4)$ & $1(2)$ & $0(0)$ \\
DXP1 & $0(1)$ & $1(1)$ & $0(1)$ \\
DXP'1 & $0(0)$ & $1(3)$ & $0(1)$ \\
DA1/4 & $0(0)$ & $0(0)$ & $1(1)$ \\
DK4 & $0(0)$ & $0(1)$ & $1(2)$ \\
DK1 & $0(0)$ & $0(0)$ & $0(0)$ \\
DN4 & $0(0)$ & $0(0)$ & $1(2)$ \\
DN1 & $0(1)$ & $0(0)$ & $2(3)$ \\
DM1 & $0(0)$ & $0(0)$ & $0(0)$ \\
DM2 & $0(0)$ & $0(0)$ & $0(0)$ \\
DLR5 & $0(0)$ & $0(0)$ & $0(0)$ \\
DLR4 & $2(4)$ & $3(4)$ & $2(3)$ \\
DLR1 & $0(0)$ & $1(3)$ & $0(0)$ \\
DLR2 & $0(1)$ & $0(0)$ & $1(3)$ \\
DLR3 & $0(0)$ & $0(0)$ & $1(2)$ \\
DHQ52 & $2(3)$ & $0(1)$ & $2(2)$ \\
Total & $8(14)$ & $7(15)$ & $11(20)$ \\
& & & \\
\hline
\end{tabular}

The coding frame of the $\mathrm{D}$ elements was temporary decided to start with $T A(T / C) T(T / A) C$ TGT in the $V_{H}$ region. All three coding frames were equally used. The total number of our data and previously described data $(29,36,37,43)$ are listed in parentheses. 
chronic lymphocytic leukemia and Burkitt's lymphoma, somatic mutation has not been observed (46-48). On the other hand, many cases of follicular lymphoma contained significant somatic mutations in the IgH variable region (26-28). Additionally, Zelenetz et al. reported that transformed diffuse lymphoma cells could mutate somatically (49). Although malignant cells may not necessarily reflect the phenomena of normal $B$ cell development, these data suggest that somatic mutation is activated after B cell maturation.

Utilization and coding frame of the D segment. All CDR-III sequenced here contained one or two D elements as reported by Siebenlist et al. (41), Ravetch et al. (32), Ichihara et al. (42), and Matsuda et al. (50).

The total number of human $D$ genes is predicted to be about 30 , since each five 9-Kb repeats contains six $\mathrm{D}$ gene families $\left(D_{M}, D_{L R}, D_{X P}, D_{A}, D_{K}\right.$, and $\left.D_{N}\right)(42)$. Until now, 17 $D$ genes have been sequenced. Four of five repeats are located between the $V_{H}$ region and the $J_{H}$ region $\left(5^{\prime}-D_{4}-D_{1}-D_{2}-D_{3}-3^{\prime}\right)$. The $D_{5}$ gene is located among $V_{H}$ genes $(50)$.

There seemed to be a certain biased use of the $D$ gene family in pre-B ALL cells, since the frequency of $D$ segment usage was as follows; $D_{L R}>D_{X P}>D_{H Q S 2}, D_{N}>D_{K}, D_{A}>D_{M}$. In adult human peripheral blood $B$ lymphocytes, $D$ segments were used as follows with low frequency; $D_{X P}>D_{N}>D_{K}, D_{L R}>D_{M}, D_{A}$ $>D_{\text {HQS2 }}(25)$. Of interest is the difference of $D$ segment usage between peripheral B cells and pre-B ALL cells. The low frequency of the $D_{K}$ and $D_{A}$ families, and relatively high frequency of the $D_{L R}$ family and $D_{\text {HQS2 }}$ in pre-B ALL cells were noticeable compared with peripheral $B$ cells. Although the reason for the low frequency of the $D_{K}$ and $D_{A}$ families remains unclear, the relatively high frequency of the $D_{L R}$ family and $D_{\text {HQS2 }}$ seems to be related to the stage of B cell ontogeny. One reason for the low frequency of $D_{L R}$ usage in peripheral $B$ cells is that $B$ cells using the first coding frame of the $D_{L R}$ family contains stop codon and must be eliminated. There is a remarkable discrepancy in the usage of the $\mathrm{D}_{\mathrm{HQ} 2}$ element between human fetal liver and peripheral B cells (23-25). The first step in IgH gene rearrangement is a $D$ to $J_{H}$ join. The initial join often involves a $\mathrm{D}_{\mathrm{HO} 52}$ gene $(23,24)$. In the murine system, the initial D-J $\mathrm{J}_{\mathbf{H}}$ rearrangement is often deleted and replaced by a secondary $D-J_{H}$ rearrangement consisting of a more $5^{\prime} D$ gene

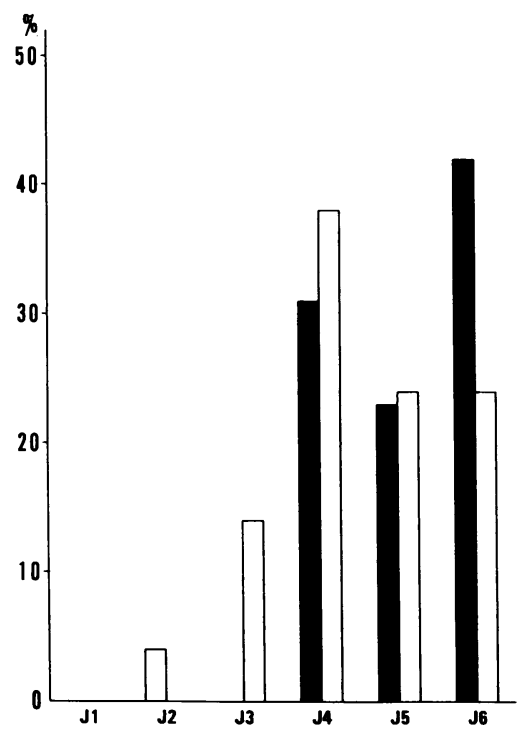

Figure 3. $\mathrm{J}_{\mathrm{H}}$ usage among human pre-B ALL cells. Black and open bars are as described in the legend to Fig. 2.

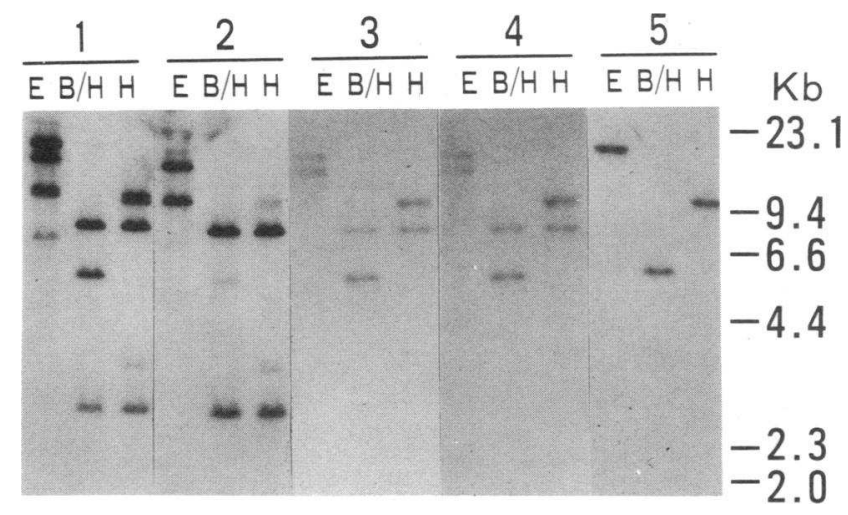

Figure 4. Southern blot hybridization of DNAs from patients C.S. and K.M. Southern blot hybridization of DNAs from the two patients (C.S. and K.M.) who had mutations in the $\mathrm{N}$ region nucleotides between initial diagnosis and relapse probed with $J_{H}$, indicates the identical rearranged pattern. (Lane 1) Patient C.S. at diagnosis; (Lane 2) Patient C.S. at relapse; (Lane 3) Patient K.M. at diagnosis; (Lane 4) Patient K.M. at relapse; (Lane 5) Germline. H, Digested with HindIII. B/H, digested with the combination of BamHI and HindIII. E, digested with EcoRI.

and a more $3^{\prime} \mathrm{J}_{\mathrm{H}}$ gene $(5,51)$. The pre-B ALL cells using the $\mathrm{D}_{\mathrm{HQ} 52}$ element might have been transformed into malignancy during an early stage of ontogeny.

On the other hand, the $D_{4}$ subgroup $\left(D_{\mathrm{XP} 4}\right.$ and $\left.D_{L R 4}\right)$ is most frequently used among $D_{X P}$ and $D_{L R}$ families. This finding concurs with Tsukada's report which showed the preferential use of the most $5^{\prime} \mathrm{D}$ in murine immature B cell lines (5). $D_{L R S}$ was not found in our sequence data, although other $D_{L R}$ families were frequently used. As mentioned above, moderately preferential usage of the $D_{4}$ subgroup and $D_{\text {HQS2 }}$, and no use of $D_{L R 5}$, might be explained by their location.

We observed three clones in which CDR-III sequences contained unusual D-D joins. The D-D joining model was first proposed by Kurosawa and Tonegawa to explain the origin of the $\mathrm{N}$ region of the murine IgH gene (44). They thought that a $D$ segment $\left(D_{a}\right)$ could join to another $D$ segment $\left(D_{b}\right)$, using a 24-mer signal spacer consisting of the end pentamer within the $D_{a}$ segment, the $D_{a}$ heptamer, and a 12 mer of spacer instead of a 23 mer, because intact $D$ segments cannot join among themselves by the 12/23 rule. Meek et al., however, proved that murine germline $\mathrm{D}$ segments could directly join with another D segment either directly or invertedly (52). In fact, other investigators also reported the existence of $D$-D joins which were observed more frequently in adult murine B cells $(18,20)$. Before our analysis, Jonsson et al. also reported two clones with D-D joins; $D_{L_{R 1}}-D_{X_{P 1} 1}$ and $D_{K_{4}}-D_{\mathrm{HQ} 52}$ from pre-B ALL (37). Furthermore, Yamada et al. reported several clones with D-D joins derived from peripheral B cells (25). Thus, in the CDR-III from human pre-B cells, the D-D joins might occur more frequently than in murine B cell differentiation.

Recent studies have shown that truncated or complete IgH chain molecules are expressed together with surrogate light chain molecules on the surface of the murine pre-B cells (22). Although the human counterpart molecule has not been demonstrated, a selection of $D$ reading frames might be also influenced by a kind of selective pressure. Our DNA study, however, suggests no biased usage of $D$ coding frames. Furthermore, some CDR-III sequences contained a stop codon. The 
transcripts should be analyzed to elucidate the selection of coding frames.

Utilization of the $J_{H}$ segment. We found a clear correlation between $J_{H}$ utilization and the $3^{\prime}$ localization of $J_{H}$. At an early stage of $B$ cells in fetal liver, $D_{\mathrm{HQS2}_{2}}-\mathrm{J} 1$ joining was frequently observed (23). During B cell differentiation, a second $D-J_{H}$ or a third D- $\mathrm{J}_{\mathrm{H}}$ might occur before $\mathrm{V}_{\mathrm{H}}-\mathrm{D}-\mathrm{J}_{\mathrm{H}}$ rearrangement is accomplished (51). In this case the most $5^{\prime} \mathrm{D}$ and the most $3^{\prime} \mathrm{J}_{\mathbf{H}}$ would join at a later stage. This explanation matches our observations, and supports the one-dimensional tracking model of recombination $(6,53)$. Schroeder et al. reported a striking gradient of $\mathrm{J}_{\mathbf{H}}$ usage in human fetal liver as follows: $\mathrm{J} 3>\mathrm{J} 4>\mathrm{J} 5$ $>\mathrm{J} 2$, J6 (24). Yamada et al. reported a different gradient of $\mathrm{J}_{\mathbf{H}}$ usage in peripheral B cells as follows: $\mathrm{J} 4>\mathrm{J} 6>\mathrm{J} 5>\mathrm{J} 3$ (25). In our findings and previously reported sequences derived from pre-B ALL cells $(29,36,37,43), \mathrm{J} 4, \mathrm{~J} 5$, and J6 segments were equally used. It is not clear at the present time whether these discrepancies are due to the different utilization of B cells in each stage of ontogeny, or the selection resulting from malignant transformation.

Mutated CDR-III sequence at relapse. 2 out of 10 patients had mutated CDR-III sequences at relapse. All of these changes were observed within the $\mathrm{N}$ region near the $\mathrm{D}$ segments; in addition, the $G$ nucleotide was most frequently substituted. Misincorporations due to the relative lack of fidelity of Taq polymerase might be the important problem with our approach. In order to rule out the possibility of Taq polymerase replication errors, we examined the genomic DNAs from these two patients three times independently, and confirmed the mutations. In the earlier studies, a cumulative error frequency was reported about $0.25 \%$ after 30 cycles of PCR (39). However, recent studies using lower $\mathrm{dNTP}$ and $\mathrm{Mg}^{2+}$ ion concentrations (200 $\mu \mathrm{M}$ each $\mathrm{dNTP}$, and $1.5 \mathrm{mM} \mathrm{MgCl}_{2}$ ), which were the same as ours, have reported a significant increase in the fidelity of Taq polymerase. Now it is recognized that the cumulative error frequency is less than $6.6 \times 10^{-5}$, and the average mutation rate is $5 \times 10^{-6}$ errors per nucleotide incorporated per cycle, assuming 25 cycles of doubling $(54,55)$.

Generally, somatic mutation has been thought to occur in mature B cells after antigenic stimulation. In the murine system, somatic mutation in antibody variable genes appeared early after primary immunization (56). In a pre-B cell line, hypermutation at the IgH locus whose rate was determined to be $0.3-1 \times 10^{-4}$ per cell generation, was reported (57). On the other hand, in human systems it is not known from what stage human B cells mutate, although somatic mutations were frequently observed in follicular B cell lymphoma (26-28, 49). Our data, however, suggests that a primary mutation might occur at specific sequences even at the stage of pre-B cell.

Recently Yamada et al. reported the usefulness of the tumor-specific CDR-III sequence to detect and monitor minimal residual disease at the level of $10^{-5}$, using the PCR amplification (43). We also reported the detection of minimal residual disease at the level of $10^{-6}$ in a patient who had received an allogeneic bone marrow transplantation using two-step PCR amplification (38). However the mutated CDR-III sequence cannot be detected, since these detection systems are based on the enormous diversity of CDR-III. The clinical usefulness of these systems, therefore, must be limited when the leukemia cells have mutated CDR-III sequences at relapse.

Structural analysis of CDR-III sequence is important to elucidate the $B$ cell repertoire. As presented here, the sequential study of clinical lymphoid tumor samples can serve as a valuable model in B cell differentiation. Additionally, a rapid cloning and sequencing method of CDR-III could be applied to many clinical fields.

\section{Acknowledgments}

We thank Dr. Yoshikazu Kurosawa for helpful advice and discussion, and Yujiro Mori and Alan F. Brunner (Aloka Co., Ltd.) for technical support for DNA sequencing.

This work was supported by grants from the Japanese Ministry of Health and Welfare.

\section{References}

1. Tonegawa, S. 1983. Somatic generation of antibody diversity. Nature (Lond.). 302:575-581.

2. Honjo, T. 1983. Immunoglobulin genes. Annu. Rev. Immunol. 1:499-528.

3. Alt, F. W., T. K. Blackwell, R. A. DePinho, M. G. Reth, and G. D. Yancopoulos. 1986. Regulation of genome rearrangement events during lymphocyte differentiation. Immunol. Rev. 89:5-30.

4. Wu, T. T., and E. A. Kabat. 1970. An analysis of the sequences of the variable regions of Bence Jones proteins and myeloma light chains and their implications for antibody complementarity. J. Exp. Med. 132:211-250.

5. Tsukada, S., H. Sugiyama, Y. Oka, and S. Kishimoto. 1990. Estimation of $D$ segment usage in initial D to $J_{H}$ joinings in a murine immature B cell line. $J$. Immunol. 144:4053-4059.

6. Yancopoulos, G. D., S. V. Desiderio, M. Paskind, J. F. Kearney, D. Baltimore, and F. W. Alt. 1984. Preferential utilization of the most $J_{\mathbf{H}}$-proximal $V_{H}$ gene segments in pre-B-cell lines. Nature (Lond.). 311:727-733.

7. Perlmutter, R. M., J. F. Kearney, S. P. Chang, and L. E. Hood. 1985. Developmentally controlled expression of immunoglobulin $\mathrm{V}_{\mathrm{H}}$ genes. Science (Wash. DC). 227:1597-1600.

8. Jeong, H. D., and J. M. Teale. 1988. Comparison of the fetal and adult functional B cell repertoires by analysis of $\mathrm{V}_{\mathrm{H}}$ gene family expression. $J$. Exp. Med. 168:589-603.

9. Dildrop, R., U. Krawinkel, E. Winter, and K. Rajewsky. 1985. V $\mathbf{H}_{\mathbf{H}}$-gene expression in murine lipopolysaccharide blasts distributes over the nine known

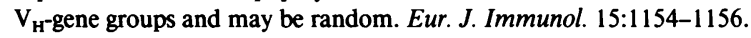

10. Wu, G. E., and C. J. Paige. 1986. $V_{H}$ gene family utilization in colonies derived from $\mathrm{B}$ and pre-B cells detected by the RNA colony blot assay. $E M B O$ (Eur. Mol. Biol. Organ.) J. 5:3475-3481.

11. Schulze, D. H., and G. Kelsoe. 1987. Genotypic analysis of B cell colonies by in situ hybridization. Stoichiometric expression of three $V_{H}$ families in adult C57BL/6 and BALB/c mice. J. Exp. Med. 166:163-172.

12. Yancopoulos, G. D., B. A. Malynn, and F. W. Alt. 1988. Developmentally regulated and strain-specific expression of murine $\mathrm{V}_{\mathrm{H}}$ gene families. J. Exp. Med. 168:417-435.

13. Sheehan, K. M., and P. H. Brodeur. 1989. Molecular cloning of the primary IgH repertoire: A quantative analysis of $\mathrm{V}_{\mathrm{H}}$ gene usage in adult mice. EMBO (Eur. Mol. Biol. Organ.) J. 8:2313-2320.

14. Alt, F. W., and D. Baltimore. 1982. Joining of immunoglobulin heavy chain gene segments: implications from a chromosome with evidence of three D-J ${ }_{\mathrm{H}}$ fusions. Proc. Natl. Acad. Sci. USA. 79:4118-4112.

15. Desiderio, S. V., G. D. Yancopoulos, M. Paskind, E. Thomas, M. A. Boss, N. Landau, F. W. Alt, and D. Baltimore. 1984. Insertion of $N$ regions into heavychain genes is correlated with expression of terminal deoxytransferase in B cells. Nature (Lond.). 31 1:752-755.

16. Landau, N. R., D. G. Schatz, M. Rosa, and D. Baltimore. 1987. Increased frequency of $\mathrm{N}$-region insertion in a murine pre-B-cell line infected with a terminal deoxynucleotidyl transferase retroviral expression vector. Mol. Cell. Biol. 7:3237-3243.

17. Lieber, M. R., J. E. Hesse, K. Mizuuchi, and M. Gellert. 1988. Lymphoid $\mathrm{V}(\mathrm{D}) \mathrm{J}$ recombination: Nucleotide insertion at signal joints as well as coding joints. Proc. Natl. Acad. Sci. USA. 85:8588-8592.

18. Feeney, A. J. 1990. Lack of $\mathrm{N}$ regions in fetal and neonatal mouse immunoglobulin V-D-J junctional sequences. J. Exp. Med. 172:1377-1390.

19. Gu, H., I. Forster, and K. Rajewsky. 1990. Sequence homologies, N sequence insertion and $J_{H}$ gene utilization in $V_{H} D_{H}$ joining: implications for the joining mechanism and the ontogenetic timing of Ly1 B cell and B-CLL progenitor generation. EMBO (Eur. Mol. Biol. Organ.) J. 9:2133-2140.

20. Bangs, L. A., I. E. Sanz, and J. M. Teale. 1991. Comparison of D, $J_{H}$ and junctional diversity in the fetal, adult, and aged B cell repertoires. J. Immunol. 146:1996-2004.

21. Ichihara, Y., H. Hayashida, S. Miyazawa, and Y. Kurosawa. 1989. Only $D_{\mathrm{FL16}}, \mathrm{D}_{\mathrm{SP2}}$, and $\mathrm{D}_{\mathrm{Q} 52}$ gene families exist in mouse immunoglobulin heavy chain 
diversity gene loci, of which $\mathrm{D}_{\mathrm{FL} 16}$ and $\mathrm{D}_{\mathrm{SP} 2}$ originate from the same primordial $\mathrm{D}_{\mathrm{H}}$ gene. Eur. J. Immunol. 19:1849-1854.

22. Gu, H., D. Kitamura, and K. Rajewsky. 1991. B cell development regulated by gene rearrangement: arrest of maturation by membrane-bound $D_{\mu}$ protein and selection of $\mathrm{D}_{\mathrm{H}}$ element reading frames. Cell. 65:47-54.

23. Nickerson, K. G., J. Berman, E. Glickman, L. Chess, and F. W. Alt. 1989. Early human IgH gene assembly in Epstein-Barr virus-transformed fetal B cell lines. Preferential utilization of the most $\mathrm{J}_{\mathrm{H}}$-proximal D segment (DQ52) and two unusual $\mathrm{V}_{\mathrm{H}^{-}}$related rearrangements. J. Exp. Med. 169:1391-1403.

24. Schroeder JR, H. W., and J. Y. Wang. 1990. Preferential utilization of conserved immunoglobulin heavy chain variable gene segments during human fetal life. Proc. Natl. Acad. Sci. USA. 87:6146-6150.

25. Yamada, M., R. Wasserman, B. A. Reichard, S. Shane, A. J. Caton, and G. Rovera. 1991. Preferential utilization of specific immunoglobulin heavy chain diversity and joining segments in adult human peripheral blood B lymphocytes. J. Exp. Med. 173:395-407.

26. Cleary, M., T. C. Meeker, S. Levy, E. Lee, M. Trela, J. Sklar, and R. Levy. 1986. Clustering of extensive somatic mutations in the variable region of an immunoglobulin heavy chain gene from a human B cell lymphoma. Cell. 44:97106.

27. Levy, R., S. Levy, M. L. Cleary, W. Carroll, S. Kon, J. Bird, and J. Sklar. 1987. Somatic mutation in human B-cell tumors. Immunol. Rev. 96:43-58.

28. Levy, S., E. Mendel, S. Kon, Z. Avnur, and R. Levy. 1988. Mutational hot spots in Ig V region genes of human follicular lymphomas. J. Exp. Med. 168:475489.

29. Bird, J., N. Galili, M. Link, D. Stites, and J. Sklar. 1988. Continuing rearrangement but absence of somatic hypermutation in immunoglobulin genes of human B cell precursor leukemia. J. Exp. Med. 168:229-245.

30. Sambrook, J., E. F. Fritsch, and T. Maniatis. 1989. Molecular Cloning: a Laboratory Manual. 2nd ed. Cold Spring Harbor Laboratory Press, Cold Spring Harbor, NY.

31. Southern, E. 1975. Detection of specific sequence among DNA fragments separated by gel electrophoresis. J. Mol. Biol. 98:503-517.

32. Ravetch, J. V., U. Siebenlist, S. Korsmeyer, T. Waldmann, and P. Leder. 1981. Structure of the human immunoglobulin mu locus: Characterization of embryonic and rearranged J and D genes. Cell. 27:583-591.

33. Kabat, E. A., T. T. Wu, M. Reid-Miller, H. M. Perry, and K. S. Gottesman. 1987. Sequences of Proteins of Immunological Interest. 4th ed. Nationa Institutes of Health publication, Bethesda, MD.

34. Berman, J. E., S. J. Mellis, R. Pollock, C. L. Smith, H. Suh, B. Heinke, C Kowal, U. Surti, L. Chess, C. R. Cantor, et al. 1988. Content and organization of human Ig $\mathrm{V}_{\mathrm{H}}$ locus: Definition of three new $\mathrm{V}_{\mathrm{H}}$ families and linkage to the $\mathrm{Ig} \mathrm{V}_{\mathrm{H}}$ locus. 1988. EMBO (Eur. Mol. Biol. Organ.) J. 7:727-738.

35. Yamada, M., S. Hudson, O. Tournay, S. Bittenbender, S. S. Shane, B. Lange, Y. Tsujimoto, A. J. Caton, and G. Rovera. 1989. Detection of minima disease in hematopoietic malignancies of the B-cell lineage by using third-complementarity-determining region (CDR-III)-specific probes. Proc. Natl. Acad. Sci. USA. 86:5123-5127.

36. Brisco, M. J., L. W. Tan, A. M. Orsborn, and A. A. Morley. 1990. Development of a highly sensitive assay, based on the polymerase chain reaction, for rare B-lymphocyte clones in a polyclonal population. Br. J. Haematol. 75:163-167.

37. Jonsson, O. G., R. K. Kitchens, F. C. Scott, and R. G. Smith. 1990 Detection of minimal residual disease in acute lymphoblastic leukemia using immunoglobulin hypervariable region specific oligonucleotide probes. Blood. 76:2072-2079.

38. Kiyoi, H., T. Naoe, K. Kitamura, T. Yamauchi, T. Ichihashi, and R. Ohno. 1991. Disappearance of minimal residual lymphoblastic leukemia cells six months after allogeneic bone marrow transplantation without GVHD. Bone Marrow Transplant. 8:59-62.

39. Saiki, R. K., D. H. Gelfand, S. Stoffel, S. J. Scharf, R. Higuchi, G. T. Horn,
K. B. Mullis, and H. A. Erlich. 1988. Primer-directed enzymic amplification of DNA with a thermosatable DNA polymerase. Science (Wash. DC). 239:487-491.

40. Prober, J. M., G. L. Trainor, R. J. Dam, F. W. Hobbs, C. W. Robertson, R. J. Zagursky, A. J. Cocuzza, M. A. Jensen, and K. Baumeister. 1987. A system for rapid DNA sequencing with fluorescent chain-terminating dideoxynucleotides. Science (Wash. DC). 238:336-341.

41. Siebenlist, U., J. V. Ravetch, S. Korsmeyer, T. Waldmann, and P. Leder. 1981. Human immunoglobulin D segments encoded in tandem multigenic families. Nature (Lond.). 294:631-635.

42. Ichihara, Y., H. Matsuoka, and Y. Kurosawa. 1988. Organization of human immunoglobulin heavy chain diversity gene loci. EMBO (Eur. Mol. Biol. Organ.) J. 7:4141-4150.

43. Yamada, M., R. Wasserman, B. Lange, B. A. Reichard, R. B. Womer, and G. Rovera. 1990. Minimal residual disease in childhood B-lineage lymphoblastic leukemia. N. Engl. J. Med. 323:448-455.

44. Kurosawa, Y., and S. Tonegawa. 1982. Organization, structure, and assembly of immunoglobulin heavy chain diversity DNA segments. J. Exp. Med. 155:201-217.

45. Lafaille, J. L., A. DeCloux, M. Bonneville, Y. Takagaki, and S. Tonegawa. 1989. Junctional sequences of $T$ cell receptor genes: implications for $T$ cell lineages and for a novel intermediate of V-(D)-J joining. Cell. 59:859-870.

46. Kipps, T. J., E. Tomhave, P. P. Chen, and D. A. Carson. 1988. Autoantibody-associated kappa light chain variable region gene expressed in chronic lymphocytic leukemia with little or no somatic mutation. Implications for etiology and immunotherapy. J. Exp. Med. 167:840-852.

47. Meeker, T. C., J. C. Grimaldi, R. O'Rourke, J. Loeb, G. Juliusson, and S. Einhorn. 1988. Lack of detectable somatic hypermutation in the $\mathrm{V}$ region of the Ig $\mathbf{H}$ chain gene of a human chronic B lymphocytic leukemia. J. Immunol. 141:3994-3998.

48. Caroll, W. L., M. Yu, M. P. Link, and S. J. Korsmeyer. 1989. Absence of Ig $\mathrm{V}$ region gene somatic hypermutation in advanced Burkitt's lymphoma. $J$. Immunol. 143:692-698.

49. Zelenetz, A. D., T. T. Chen, and R. Levy. 1991. Histologic transformation of follicular lymphoma to diffuse lymphoma represents tumor progression by a single malignant B cell. J. Exp. Med. 173:197-207.

50. Matsuda, F., K. H. Lee, S. Nakai, T. Sato, M. Kodaira, S. Q. Zong, H. Ohno, S. Fukuhara, and T. Honjo. 1988. Dispersed localization of D segments in the human immunoglobulin heavy-chain locus. EMBO (Eur. Mol. Biol. Organ.) J. 7:1047-1051

51. Reth, M. G., S. Jackson, and F. W. Alt. 1986. $\mathrm{V}_{\mathrm{H}} \mathrm{DJ}_{\mathrm{H}}$ formation and $\mathrm{DJ}$ replacement during pre-B differentiation: non-random usage of gene segments. EMBO (Eur. Mol. Biol. Organ.) J. 5:2131-2138.

52. Meek, K. D., C. A. Hasemann, and J. D. Capra. 1989. Novel rearrangements at the immunoglobulin D locus: Inversions and fusions add to IgH somatic diversity. J. Exp. Med. 170:39-57.

53. Wood, C., and S. Tonegawa. 1983. Diversity and joining segments of mouse immunoglobulin heavy chain genes are closely linked and in the same orientation: implications for the joining mechanism. Proc. Natl. Acad. Sci. USA. 80:3030-3034.

54. Gelfand, D. H., and T. J. White. 1990. Thermostable DNA polymerase. In PCR Protocols. M. A. Innis, D. H. Gelfand, J. J. Shinsky, and T. J. White, editors. Academic Press, San Diego, CA. 129-141.

55. Erlich, H. A., D. Gelfand, and J. J. Sninsky. 1991. Recent advances in the polymerase chain reaction. Science (Wash. DC). 252:1643-1651.

56. Levy, N. S., U. V. Malipiero, S. G. Lebecque, and P. J. Gearhart. 1989. Early onset of somatic mutation in immunoglobulin $\mathrm{V}_{\mathbf{H}}$ genes during the primary immune response. J. Exp. Med. 169:2007-2019.

57. Wabl, M., P. D. Burrows, A. V. Gabain, and C. Steinberg. 1985. Hypermutation at the immunoglobulin heavy chain locus in a pre-B-cell line. Proc. Natl. Acad. Sci. USA. 82:479-482. 